\title{
Nitrogen deposition changes the keystone taxa of soil microorganisms and indirectly affects plant aboveground biomass in desert steppe regions
}

YeHe ( $\nabla$ nmyehe1995@outlook.com )

Inner Mongolia Agricultural University https://orcid.org/0000-0001-6291-5650

Mei Hong

Inner Mongolia Agricultural University

Xuehui Xu

Zhiwei Liang

$\mathrm{Na}$ Jiang

Nare Tu

Zhendan Wu

\section{Research Article}

Keywords: Plant community structure, Soil microorganisms, Plant-microbial interaction, Nitrogen deposition, Desert steppe

Posted Date: March 7th, 2022

DOI: https://doi.org/10.21203/rs.3.rs-1354926/v1

License: (a) (i) This work is licensed under a Creative Commons Attribution 4.0 International License. Read Full License 


\section{Abstract}

Aims Nitrogen $(\mathrm{N})$ deposition is an important component of global change and threatens terrestrial biodiversity. In past decades, the response of the relationship between plants and soil microbes to $\mathrm{N}$ deposition has attracted considerable attention. Keystone microbial taxa have been proven to provide nutrients for specific plant growth, especially in nutrient-poor desert steppe ecosystems. However, the effects of $\mathrm{N}$ deposition on plant and soil microbial community interactions in desert steppe regions remain poorly understood.

Methods To investigate these effects, a six-year $\mathrm{N}$-addition field experiment was conducted in a Stipa breviflora desert steppe in Inner Mongolia, Northwest China. Four N treatment levels (N0, N1, N2, and N3, corresponding to $0,30,50$, and $100 \mathrm{~kg} \mathrm{~N} \mathrm{ha}^{-1} \mathrm{yr}^{-1}$, respectively) were applied to simulate atmospheric $\mathrm{N}$ deposition.

Results The results showed that (1) after the six-year $\mathrm{N}$ deposition simulation, the plant aboveground biomass did not increase, but the plant community structure changed; (2) in desert steppes, the relationship between microorganism communities and Neopallasia pectinata was strengthened by $\mathrm{N}$ addition, while that between microorganism communities and $S$. breviflora was simplified; and (3) N deposition indirectly affected the plant biomass in desert grasslands, mainly along key-stone microbial taxa pathways.

Conclusions Together, these results suggest that $\mathrm{N}$ deposition can alter plant community structures by affecting the relationships between plants and soil microorganisms in desert steppes. These findings contribute to a comprehensive understanding of the effects of atmospheric $\mathrm{N}$ deposition on the ecological health and function of desert steppes.

\section{Introduction}

Desert steppes are unique transitional ecotones located between steppe and desert regions in Eurasia (Chen et al., 2017; Wu et al., 2021). The desert steppe region of Inner Mongolia has a simple community structure, lacks water resources, and has poor soil nutrients. Therefore, it is considered a fragile ecosystem, especially under the background of global climate change (Angerer et al., 2008). In recent years, global climate change has led to an increasing atmospheric nitrogen $(\mathrm{N})$ deposition trend in China (Liu et al., 2013), and the average amount of $\mathrm{N}$ deposited in China was estimated at $20.4 \pm 2.6 \mathrm{~kg} \mathrm{~N} \mathrm{ha}^{-1}$ $\mathrm{yr}^{-1}$ from 2011-2015 (Yu et al., 2019). $\mathrm{N}$ deposition has been considered the third-greatest threat to global terrestrial biodiversity (Payne et al., 2017). According to previous studies, atmospheric $\mathrm{N}$ deposition negatively affects the plant and soil microbial community diversity in terrestrial ecosystems (Bobbink et al., 2010; Zhang et al., 2018). Biodiversity is not only inherently precious but also bolsters the functioning abilities of ecosystems and provides reliable ecosystem services on Earth (Borer et al., 2014; Hautier et al., 2014; Yang et al., 2019). To maintain biodiversity, there is an urgent need to understand the responses of biodiversity to long-term $\mathrm{N}$ deposition in desert steppe ecosystems (Yang et al., 2019). 
$\mathrm{N}$ deposition usually leads to an increase in plant productivity but a decrease in plant diversity. With some plant species becoming rare, $\mathrm{N}$ depositions can even result in species extinctions (Stevens et al., 2004; Hautier et al., 2009; Yu et al., 2019). N deposition affects plants through many factors, such as nutrient imbalances and interspecific competition (Payne et al., 2017). Additionally, shifts in plant communities do not occur in isolation, and plant composition changes can influence the soil bacterial and fungal communities through cascade effects (Erisman et al., 2013; Payne et al., 2017). However, soil microbial communities can also influence plant fitness in various ways, such as via the decomposition, nutrient cycling, and nutrient acquisition processes (Berg and Smalla, 2009; Schlatter et al., 2015). The interactions between plants and the associated soil microbial communities are so intertwined that they can be considered as a whole entity that is subjected to environmental changes and selection (ZilberRosenberg and Rosenberg, 2008; Panke-Buisse et al., 2015; Hortal et al., 2017). A previous study showed that plant productivity is positively correlated with the proportion of keystone microbial taxa (Fan et al., 2020). Key-stone microbial taxa are highly connected taxa that exert a considerable influence on microbiome structure and functioning, either individually or in a guild, irrespective of their spatial or temporal abundance (Banerjee et al., 2018). These microbial species often coexist in space and time and form clusters in microbial ecological networks; these clusters have been proven to provide nutrients for specific plant growth, especially in nutrient-poor desert steppe ecosystems (Delgado-Baquerizo et al., 2020).

$\mathrm{N}$ is an essential element for plant growth, and plants and microbes compete for $\mathrm{N}$ in soil. Increased plant-microbial competition for $\mathrm{N}$ can result in decreased soil $\mathrm{N}$ availabilities and microbial activities (Hu et al., 2001; Dunn et al., 2006; Shao et al., 2018). For instance, an N increase can depress the soil microbial activity by altering the metabolic capabilities of soil bacterial communities (Ramirez et al., 2012). Additionally, accumulated evidence suggests that $\mathrm{N}$ deposition can reduce the microbial biomass and change the microbial community compositions in diverse ecosystems (Treseder, 2008; Contosta et al., 2015). Increased $\mathrm{N}$ availabilities reduce the fungal biomass via changes in plant-specific exudates and alterations in nutrient competitions between plants and rhizosphere microbes (Bardgett et al., 1999; Zhang et al., 2018). Many ecological studies have highlighted the importance of plant-soil microorganism feedbacks and shifts in feedback effects associated with soil microbial community compositions, as these processes affect the coexistence and community compositions of plants (Bever, 2003; Reynolds et al., 2003; Lau and Lennon, 2011). Although the effects of plant-soil microorganism interactions on plant ecology have been widely studied, little research has addressed how belowground microbial communities influence plant biomass in nutrient-poor desert steppes (Kardol et al., 2007; Lau and Lennon, 2011; Hortal et al., 2017; van der Putten, 2017). Additionally, the ways in which N depositions affect this process are also unknown. In this study, we established a 6-year simulated $\mathrm{N}$ deposition experiment in the desert steppe region of Inner Mongolia, China. The changes that occurred in the composition and diversity of the plant and soil microbial communities in response to elevated $\mathrm{N}$ deposition were explored. We hypothesized that (i) increased $\mathrm{N}$ availability would significantly affect the plant community composition and biomass at all $\mathrm{N}$ input levels and (ii) changes in the plant community 
composition would be comprehensively affected by the keystone soil microorganisms and $\mathrm{N}$ deposition amounts.

\section{Materials And Methods}

Field experiment setup

The field experiment was established at Siziwang Banner $\left(41^{\circ} 46^{\prime} 43.6^{\prime \prime} \mathrm{N}, 111^{\circ} 53^{\prime} 41.7^{\prime \prime} \mathrm{E}\right.$, with an elevation of $1456 \mathrm{~m}$ ), an arid region in Inner Mongolia, northern China. The average annual precipitation in this region is $280 \mathrm{~mm}$, with cumulative precipitation falling during the growing season (May to October) constituting approximately $70 \%$ of the total precipitation throughout the whole year. The annual average temperature in the study region is $3.4^{\circ} \mathrm{C}$. The soil at the study site has a sandy loam texture and is classified as a Haplic Calcisol based on the Food and Agricultural Organization (FAO) soil classification system of the United Nations. The plant community at the study site is dominated by Stipa breviflora Griseb., Convolvulus ammannii Desr., Kochia prostrata (L.) Schrad. and Cleistogenes songorica (Roshev.) Ohwi.

The long-term simulated $\mathrm{N}$ deposition experiments were established at the desert steppe site in December 2015. Four $\mathrm{N}$-addition treatments were applied: i) the control treatment (N0, no N addition), ii) first $\mathrm{N}$ addition treatment ( $\mathrm{N} 1,30 \mathrm{~kg} \mathrm{~N} \mathrm{ha}^{-1} \mathrm{yr}^{-1}$ ), iii) second $\mathrm{N}$ addition treatment ( $\left.\mathrm{N} 2,50 \mathrm{~kg} \mathrm{~N} \mathrm{ha}^{-1} \mathrm{yr}^{-1}\right)$, and iv) third $\mathrm{N}$ addition treatment $\left(\mathrm{N} 3,100 \mathrm{~kg} \mathrm{~N} \mathrm{ha}^{-1} \mathrm{yr}^{-1}\right)$. To mirror the natural seasonal $\mathrm{N}$ deposition pattern from May to September, $\mathrm{NH}_{4} \mathrm{NO}_{3}$ was mixed with purified water $(10.0 \mathrm{~L}$ per plot; in the $\mathrm{N} 0$ treatment, plots received only purified water) and sprinkled evenly on each plot using a sprayer to simulate wet deposition. From October of the same year to April of the following year, $\mathrm{NH}_{4} \mathrm{NO}_{3}$ was mixed with soil ( $1.0 \mathrm{~kg}$ sand per plot; in the NO treatment, plots received only soil) and broadcasted evenly by hand to simulate dry deposition. These experiments were planned according to a randomized block design with 4 replicate blocks, each of which was $31 \times 31 \mathrm{~m}$ in size. The blocks were separated by 1-m walkways. Four plots were treated with each of the four $\mathrm{N}$-addition levels in each block. Each plot measured $7 \times 7 \mathrm{~m}$, and the plots were separated by 1 -m walkways.

Plant species composition and biomass

In August 2021, at the peak of the growing season, we randomly arranged three $0.5 \times 0.5-\mathrm{m}$ subplots in each plot, the edges of which were parallel to but at least $1 \mathrm{~m}$ away from the edges of the plot. We harvested all aboveground plant parts, sorted the plants into species, recorded the species richness and abundance (number of individuals), dried the plants at $65^{\circ} \mathrm{C}$ for $48 \mathrm{~h}$ and weighed the samples to $0.01 \mathrm{~g}$ to measure the aboveground biomass of each species in each subplot.

Soil microbial communities

Soil samples were collected randomly by taking thirty soil cores (with 1-cm diameters and 10-cm depths); these cores were then mixed to yield one sample per plot. After roots and stones were removed and the 
soil was gently mixed, each sample was placed into a sterile plastic bag. The samples were immediately stored on dry ice and transported to the laboratory within 6 hours.

The microbial community genomic DNA was extracted from $0.5 \mathrm{~g}$ soil using an E.Z.N.A. ${ }^{\circledR}$ soil DNA Kit (Omega Bio-Tek, Norcross, GA, U.S.) according to the manufacturer's instructions. The DNA extract was then checked on a $1 \%$ agarose gel, and the DNA concentration and purity were determined with a NanoDrop 2000 UV-vis spectrophotometer (Thermo Scientific, Wilmington, USA). To determine the soil bacterial and fungal community composition and diversity, amplicon surveys of the 16S and ITS rRNA were implemented. The V3-V4 hypervariable regions of the $16 \mathrm{~S}$ rRNA gene were amplified using the $338 \mathrm{~F}$ (5'-ACTCCTACGGGAGGCAGCAG-3') and 806R (5'-GGACTACHVGGGTWTCTAAT-3') primer sets. The ITS1F (5'-CTTGGTCATTTAGAGGAAGTAA-3') and ITS2R (5'-GCTGCGTTCTTCATCGATGC-3') primers were used to amplify the ITS1 region of the fungal rRNA. PCR amplification of the 16S and ITS rRNA genes was performed through the following steps: an initial denaturation at $95^{\circ} \mathrm{C}$ for 3 min followed by 27 denaturing cycles at $95^{\circ} \mathrm{C}$ for $30 \mathrm{~s}$ each, annealing at $55^{\circ} \mathrm{C}$ for $30 \mathrm{~s}$ and extension at $72^{\circ} \mathrm{C}$ for $45 \mathrm{~s}$, a single extension at $72^{\circ} \mathrm{C}$ for $10 \mathrm{~min}$, and a terminal temperature of $4^{\circ} \mathrm{C}$. The PCR mixtures contained $5 \times 4$ $\mu \mathrm{L}$ of TransStart FastPfu buffer, $2.5 \mathrm{mM}$ dNTPs at $2 \mu \mathrm{L}, 0.8 \mu \mathrm{L}$ forward primer $(5 \mu \mathrm{M}), 0.8 \mu \mathrm{L}$ reverse primer $(5 \mu \mathrm{M}), 0.4 \mu \mathrm{L}$ TransStart FastPfu DNA Polymerase, $10 \mathrm{ng}$ template DNA, and finally up to $20 \mu \mathrm{L}$ $\mathrm{dd}_{2} \mathrm{O}$. The PCR tests were performed in triplicate. The PCR product was extracted from a $2 \%$ agarose gel, purified using an AxyPrep DNA Gel Extraction Kit (Axygen Biosciences, Union City, CA, USA) according to the manufacturer's instructions and quantified using a Quantus ${ }^{\mathrm{Tm}}$ Fluorometer (Promega, USA).

The purified amplicons were pooled in equimolar amounts and paired-end sequenced on an Illumina MiSeq PE300/NovaSeq PE250 platform (Illumina, San Diego, USA) according to the standard protocols established by Majorbio Bio-Pharm Technology Co. Ltd. (Shanghai, China). The raw reads were deposited into the National Center for Biotechnology Information (NCBI) Sequence Read Archive (SRA) database (accession number: SRP356315).

The raw 16 S and ITS rRNA gene sequencing reads were demultiplexed, quality-filtered using fastp version 0.20.0 (Chen et al., 2018) and merged using FLASH version 1.2.7 (Magoc and Salzberg, 2011) with the following criteria: (i) the 300-bp reads were truncated at any site with an average quality score $<20$ over a 50-bp sliding window, truncated reads shorter than $50 \mathrm{bp}$ were discarded, and reads containing ambiguous characters were also discarded; (ii) only overlapping sequences longer than $10 \mathrm{bp}$ were assembled according to their overlapped sequences, the maximum mismatch ratio of the overlapping region was set to 0.2 , and reads that could not be assembled were discarded; (iii) the samples were distinguished according to the barcode and primers, and the sequence direction was adjusted through exact barcode matching and 2-nucleotide mismatches in the primer matching process.

Operational taxonomic units (OTUs) with 97\% similarity cut-off values (Stackebrandt and Goebel, 1994; Edgar, 2013) were clustered using UPARSE version 7.1 (Edgar, 2013), and chimeric sequences were identified and removed. The taxonomy of each OTU representative sequence was analysed using the RDP 
Classifier version 2.2 (Wang et al., 2007) against the 16 S and ITS rRNA databases with a confidence threshold of 0.7 .

\section{Statistical analysis}

Microsoft Excel 2019 and R were used for the statistical data analyses. All figures were illustrated using Origin 2021 software. The alpha diversity values of the plant and soil microbial communities were calculated based on Shannon's diversity $\left(\mathrm{H}^{\prime}\right)$ index according to the following formula: $H^{\prime}=-\Sigma \mathrm{P}_{\mathrm{i}} \ln \mathrm{P}_{\mathrm{i}}$ (Shannon et al., 1950). The significant differences among $\mathrm{N}$-addition levels were obtained separately for the above-ground plant biomass and the relative abundance of correlated microbes using a one-way analysis of variance (ANOVA) followed by Tukey's honestly significant difference test $(P<0.05)$. The beta diversity values of the plant and soil microbial communities were visualized with nonmetric multidimensional scaling (NMDS) plots based on the Bray-Curtis similarity matrix.

Correlation network analysis. We performed a network analysis to assess the complexity of the soil microbial community and identify potential keystone taxa for each plant. To avoid spurious correlations, we selected the top 150 dominant bacterial genera and 150 dominant fungal genera; these genera accounted for the top $92.18 \%$ of the relative bacterial abundance and $97.77 \%$ of the relative fungal abundance. Spearman's rank correlation was used to assess the associations between plant and microbial taxa as well as the associations among $S$. breviflora, Neopallasia pectinata, and keystone microbial taxa. Moreover, multiple comparison corrections were performed on the Spearman's rank correlation results using the false discovery rate correction method (Benjamini and Hochberg, 1995). All possible pairwise Spearman's rank correlations between the relevant genera were calculated with the VEGAN, IGRAPH, and HMISC packages. Correlation coefficients greater than 0.6 with corresponding $P$ values below 0.05 were considered statistically robust and were included when generating the networks. The network structures were explored and visualized with Cytoscape 3.8.0.

Structural equation modelling (SEM). The SEM analyses were performed with the "piecewise SEM" package in $\mathrm{R}$ version 4.1.2. SEM was used to investigate the direct and indirect effects of $\mathrm{N}$ additions on the $S$. breviflora biomass, $N$. petinata biomass, and key stone microbial taxa. The overall fit of the final piecewise SEM results was evaluated using Fisher's $C$ and $P$ values based on the piecewise SEM package (Lefcheck, 2016).

\section{Results}

Plant community composition, diversity and biomass

The $\mathrm{N}$-addition treatments did not affect the aboveground plant biomass, while the plant community composition was significantly altered (Figs. 1A and B). The relative abundance of S. breviflora gradually decreased, and this species was replaced by $N$. petinata. However, the relative abundance of $A$. scoparia increased in the N1 treatment. In the N2 and N3 treatments, the relative abundances of $N$. petinata were 
highest. The $\mathrm{N}$ additions did not significantly reduce the Shannon's index values of the plant communities (Fig. 1C). The N1 and N2 treatments tended to increase the plant diversity, whereas the N3 treatment did not significantly decrease the plant diversity. The NMDS plots revealed separations between the plant community samples collected from the different $\mathrm{N}$-addition treatments (Fig. 1D). The treatments did affect the composition of the plant communities.

Soil microbial abundances at the phylum and genus levels

The dominant bacterial phyla (relative abundances $>5 \%$ ) across all soil samples were Actinobacteriota, Proteobacteria, Acidobacteriota, and Chloroflexi, which together accounted for more than $83.46 \%$ of the total sequences (Fig. 2A). The dominant fungal phyla across all the soils were Ascomycota, Basidiomycota, and Mortierellomycota, which together accounted for more than $97.26 \%$ of the total sequences (Fig. 2B). The relative abundance of Actinobacteriota gradually increased as the amount of $\mathrm{N}$ added increased. In particular, the relative abundance of Basidiomycota was highest in the N1 treatment, followed by in the N2, N3, and N0 treatments. This may have been related to the growth of $A$. scoparia plants treated under $\mathrm{N} 1$.

The dominant bacterial genus (relative abundance $>5 \%$ ) across all soils was Rubrobacter, which accounted for more than $13.42 \%$ of the total sequences (Fig. 2C). The dominant fungal genera across all soils were Sarocladium, Knufia, Marasmius, and Gibberella, which together accounted for more than $30.77 \%$ of the total sequences (Fig. 2D). The relative abundance of Rubrobacter was highest in the N2 treatment, followed by in the N1, N0, and N3 treatments. However, the Marasmius abundance was highest in N1, followed by in N2, N0, and N3.

Soil microbial diversity and community structure

The $\mathrm{N}$ additions did not significantly reduce the Shannon's index values of the bacterial communities (Fig. 3A). The Shannon's index of bacteria was highest in the N3 treatment, followed by in the N2, N1, and N0 treatments. The NMDS plot revealed clear separations among the bacterial community samples collected from different $\mathrm{N}$-addition treatments (Fig. 3B). The $\mathrm{N}$ additions did not significantly reduce the Shannon index values of the fungal communities (Fig. $3 \mathrm{C}$ ). For the fungal communities, the four $\mathrm{N}$-addition treatments were not clearly separated in the NMDS plot (Fig. 3D).

Plant and soil microbe network

Soil microbial genera were found to be associated with plant species based on the Spearman correlation results (Fig. 4). Specifically, some bacterial taxa (Microvirga, unclassified_f_Beijerinckiaceae, norank_f_norank_o_Rhizobiales, norank_f_Beijerinckiaceae, Skermanella, and unclassified_f_Xanthobacteraceae) showed significantly positive correlations with S. breviflora, while Microvirga, unclassified_f_Beijerinckiaceae, norank_f_Beijerinckiaceae, and Skermanella were negatively correlated with $N$. petinata. Geminibasidium was positively and significantly correlated with $S$. breviflora. Some members of the bacterial community (Keissleriella, norank_f_norank_o_Gaiellales, and 
unclassified_f_Nitrosococcaceae) showed significant positive relationships with $N$. petinata, while unclassified_f_Nitrosococcaceae was negatively correlated with $S$. breviflora. The fungal community (Neodidymelliopsis and Phlyctochytrium) showed significant positive correlations with N. petinata, while Neodidymelliopsis and Phlyctochytrium were negatively correlated with S. breviflora. Lecythophora, Cephaliophora, Oomyces, Mycocalicium, and Dinemasporium were negatively and significantly correlated with $N$. petinata. Trematosphaeria was negatively and significantly correlated with A. tenuissimum. Didymella, Coniochaeta, unclassified_f_Stephanosporaceae, and Rhizophagus were negatively and significantly correlated with $C$. ammannii. $A$. scoparia was positively and significantly correlated with $A$. mongolicum. S. breviflora was negatively and significantly correlated with $N$. petinata. Strong correlations were found among S. breviflora, N. petinata, and some microbial taxa.

The network complexity varied considerably between the two studied plants (Fig. 5). For example, compared to $N$. petinata, the soil microbial communities originating from $S$. breviflora had lower complexity and fewer edges. The network structure was most pronounced between $N$. petinata and the microbial communities, largely owing to the increased correlations between bacteria and fungi. $N$. petinata was many negatively correlated pathways with $S$. breviflora. The microorganisms that were positively correlated with $S$. breviflora were all members of Proteobacteria. The fungi that were negatively correlated with N. petinata were all members of Ascomycota.

Effects of $\mathrm{N}$ addition on the correlations between plant and soil microbial communities

The experimentally elevated $\mathrm{N}$ deposition amounts significantly decreased the positive correlations between bacterial taxa and $S$. breviflora $(P<0.05$, Fig. 6$)$. The relative abundance of the bacterial taxa that were positively correlated with $S$. breviflora gradually decreased as the $\mathrm{N}$ addition amount increased. However, the relative abundances of the bacterial and fungal taxa that were negatively correlated with $S$. breviflora gradually decreased as more $\mathrm{N}$ was added. $\mathrm{N}$ addition significantly decreased the negative correlations between bacterial taxa and $N$. petinata $(P<0.05$, Fig. 6$)$. The relative abundances of the bacterial taxa that were negatively correlated with $N$. petinata gradually decreased as the $N$ addition amount increased. The fungal taxa that were positively correlated with $N$. petinata, in contrast to the bacterial taxa, significantly responded to $\mathrm{N}$ addition $(P<0.05$, Fig. 6$)$. In particular, the relative abundances of the microbial taxa that were positively correlated with $N$. petinata were lowest in the N1 treatment, followed by those in the N2, N0, and N3 treatments.

As the SEM results illustrated, the N-induced changes in S. breviflora and N. petinata biomasses in the studied plant communities were affected by different pathways (Fig. 7). The addition of $\mathrm{N}$ directly impacted the relative abundances of the microbial taxa correlated with S. breviflora and N. petinata. Moreover, $\mathrm{N}$ addition had a nonsignificant direct effect on the biomasses of the two plant species $(P>$ 0.05). The positively and negatively correlated microbes had a direct, nonsignificant effects on the biomasses of the two plant species $(P>0.05)$. Therefore, the effects of $\mathrm{N}$ addition on the biomasses of the two plant species reflected a combination of direct and indirect effects. However, $\mathrm{N}$ addition mainly 
affected the biomasses of both plant species by inhibiting the microbial taxa that were negatively correlated with the two plant species.

\section{Discussion}

Our experimental results showed that the sixth-year $\mathrm{N}$ deposition did not induce any significant increase in the aboveground plant biomass but did change the plant community structure. In contrast to our hypothesis, the plant aboveground biomass was not significantly affected by the simulated $\mathrm{N}$ deposition. Some results of previous studies have shown that the increase in aboveground net primary production (ANPP) as $\mathrm{N}$ is added stabilizes after approximately $10.5 \sim 12.0 \mathrm{~g} \mathrm{~N} \mathrm{~m}^{-2} \mathrm{yr}^{-1}$ is added in desert steppe regions (Bai et al., 2010; Tang et al., 2017). However, the amount of $\mathrm{N}$ added in our study did not exceed this threshold. Therefore, the nonsignificant biomass increases observed herein may have been due to water constraints (Su et al., 2013). This finding is in line with the theoretical predictions of the multiple resource colimitation theory (Harpole et al., 2011). The effects of $\mathrm{N}$ additions on plant communities largely depend on the water availability (Delgado-Baquerizo et al., 2013; Ma et al., 2020). Additionally, water is another limiting factor in desert steppe ecosystems. Thus, in this work, $\mathrm{N}$ addition enhanced the aboveground biomass of the annual $N$. petinata. In contrast to the strong positive effects of $\mathrm{N}$ addition on the $N$. petinata biomass, $\mathrm{N}$ detrimentally affected the aboveground biomass of the perennial grass $S$. breviflora. Previous studies have also reported that fast-growing annuals, which are usually abundant only in the early stages of grassland succession, can almost completely replace perennials in mature sites (Bai et al., 2010). The rapid growth of annuals is facilitated by their species-specific traits, including their abundant seed production, rapid growth, and tall stature. In contrast, the decline in the abundance of perennials could be attributable to their conservative resource-use strategies (Bai et al., 2010). Moreover, another ecological adaptive strategy, the $\mathrm{r} / \mathrm{K}$ selection theory, might be reflected in the results; forbs (which grow faster as r-strategists) increased at the expense of decreased native perennial grasses (which grow slowly as K-strategists) (Gadgil and Solbrig, 1972; Ma et al., 2020). In addition to the mechanisms discussed above, some microbial mechanisms may mediate plant growth in desert steppes.

Soil microorganisms play essential roles in regulating multiple ecosystem services, including plant productivity and nutrient cycling, in natural terrestrial ecosystems (Fan et al., 2021). The experimental results obtained under all $\mathrm{N}$ addition treatments showed that $\mathrm{N}$ addition did not significantly decrease the soil microbial diversity. Our soil microbial diversity findings regarding its responses to $\mathrm{N}$ inputs were consistent with those reported in other desert steppe regions (McHugh et al., 2017; Huang et al., 2021), indicating that plants may mitigate the detrimental effects of $\mathrm{N}$ deposition on soil biodiversity (Shao et al., 2018). However, in this work, the soil microbial community structure was affected by the different $\mathrm{N}$ addition amounts. The NMDS analysis depicted that all $\mathrm{N}$-addition treatments significantly affected the structure of the soil bacterial communities rather than the soil fungal communities. Studies from arid and semiarid grasslands have shown that drought promotes the destabilizing properties of soil bacteria but not fungi and thus has a prolonged effect on bacterial communities and their cooccurrence networks via 
changes in the vegetation composition and the resultant reductions in soil moisture (de Vries et al., 2018; Fan et al., 2020; Wang et al., 2020).

Plants and soil microbes can have direct coevolutionary relationships, and their relationships constitute important systems (Keymer and Lankau, 2017). In this work, we used correlation networks to identify keystone taxa in the soil microbial community, and the relative abundances of these keystone taxa largely determined the plant community composition and biomass after almost six years of different $\mathrm{N}$ treatments. $\mathrm{N}$ deposition simplified the relationship network between $\mathrm{S}$. breviflora and microorganisms and decreased the relative abundance of microorganisms that were positively correlated with the $S$. breviflora biomass. However, the relationships between $N$. petinata and soil microbial taxa were more abundant in the network, and the relative abundance of microorganisms that were positively correlated with the $N$. petinata biomass increased. Similarly, a recent study indicated that the biodiversity of the keystone microbiome is essential for supporting plant production (Chen et al., 2020; Fan et al., 2021). This is because the performance of plants greatly depends on the ability of the soil microbiome to uptake nutrients and protect the plants against stresses (Bakker et al., 2018). To put it simply, there are a larger number of these keystone microorganisms in soils with higher nutrient availabilities and higher plant productivities. We further found that the microorganisms that were positively correlated with the $S$. breviflora biomass were all members of Alpha-Proteobacteria. Alpha-Proteobacteria have been considered copiotrophs in previous studies and might play important roles in enzyme activities (Chen et al., 2020; Zhang et al., 2022). Moreover, the keystone taxa Skermanella and Microvirga are members of Alpha-Proteobacteria and participated in S. breviflora growth via symbiotic $\mathrm{N}$ fixation pathways (Li et al., 2020; Zhang et al., 2022). Our study shows that $\mathrm{N}$ deposition reduces the $S$. breviflora biomass and the relative abundances of these keystone microorganisms, thus leading to an increase in the N. petinata biomass. We showed that $\mathrm{N}$ deposition significantly impacted the relative abundances of Lecythophora, Oomyces, Mycocalicium, and Dinemasporium, members of Ascomycota in the studied desert steppe. We further found that the microorganisms that were negatively correlated with the $N$. petinata biomass were all members of Ascomycota. This was consistent with previous studies in which oligotrophic Ascomycetes were usually dominant under drought conditions with limited carbon or nutrient availabilities (Chen et al., 2017; Wang et al., 2020). Therefore, $N$ deposition reduced the negatively correlated microorganism abundance and increased the N. petinata biomass. While the addition of $\mathrm{N}$ did not directly affect the $S$. breviflora or N. petinata biomasses, it did directly (and significantly) affect the soil microbial community, which then subsequently affected the $S$. breviflora and $N$. petinata biomasses. The SEM results showed that $\mathrm{N}$ addition and the related microorganisms explained more than $60 \%$ of the variance in the $S$. breviflora and $N$. petinata biomasses but did not directly affect the $S$. breviflora or $N$. petinata biomasses. Therefore, $\mathrm{N}$ deposition indirectly affects plant biomasses in desert grasslands mainly through pathways associated with keystone microbial taxa. Among these pathways, the inhibition or promotion of negatively correlated microorganisms represent the main factor. These findings support our hypothesis that changes in plant community composition are comprehensively affected by keystone microbial taxa and $\mathrm{N}$ deposition. 


\section{Conclusion}

Overall, following the six-year simulated $\mathrm{N}$ deposition experiment, the plant aboveground biomass did not increase, but the plant community structure was altered. At the same time, the $\mathrm{N}$-addition treatments did not significantly decrease the soil microbial diversity, whereas the treatments did change the soil microbial community structure. $\mathrm{N}$ deposition indirectly affected the plant biomass in the studied desert grassland, mainly through pathways associated with keystone microbial taxa, among which the inhibition or promotion negatively correlated microorganisms was the main factor. Together, these results suggest that $\mathrm{N}$ deposition alters the keystone taxa of soil microorganisms and indirectly affects the plant aboveground biomass in desert steppes.

\section{Declarations}

This work was supported by the National Natural Science Foundation of China (No. 31860136, No. 31560156), and the Inner Mongolia Autonomous Region graduate Scientific research innovation project. We thank the Siziwang Research Station of Inner Mongolia Academy of Agricultural \& Animal Husbandry Sciences for providing access to the study site.

The authors declare that they have no conflicts of interest. All authors contributed to the study conception and design. Material preparation, data collection and analysis were performed by He Ye, Mei Hong, Xuehui XU, Zhiwei Liang, Na Jiang, Nare Tu and Zhendan Wu. The first draft of the manuscript was written by He Ye and all authors commented on previous versions of the manuscript. All authors read and approved the final manuscript.

The datasets generated during and analysed during the current study are available from the corresponding author on reasonable request.

\section{Acknowledgements}

This work was supported by the National Natural Science Foundation of China (nos. 31860136 and 31560156) and the Inner Mongolia Autonomous Region graduate scientific research innovation project. We thank the Siziwang Research Station of Inner Mongolia Academy of Agricultural \& Animal Husbandry Sciences for providing access to the study site. The authors declare that they have no conflicts of interest.

\section{References}

1. Angerer J, Han G, Fujisaki I, Havstad K (2008) Climate Change and Ecosystems of Asia With Emphasis on Inner Mongolia and Mongolia. Rangelands 30:46-51. doi:10.2111/1551501X(2008)30[46:CCAEOA]2.0.CO;2

2. Bai Y, Wu J, Clark CM, Naeem S, Pan Q, Huang J, Zhang L, Han X, OF N ENRICHMENT ON ECOSYSTEM FUNCTIONING (2010) Tradeoffs and thresholds in the effects of nitrogen addition on 
biodiversity and ecosystem functioning: evidence from inner Mongolia Grasslands: IMPACT. Glob Change Biol 16:358-372. doi:10.1111/j.1365-2486.2009.01950.x

3. Bakker PAHM, Pieterse CMJ, de Jonge R, Berendsen RL (2018) Soil-Borne Leg Cell 172:1178-1180. doi:10.1016/j.cell.2018.02.024

4. Banerjee S, Schlaeppi K, van der Heijden MGA (2018) Keystone taxa as drivers of microbiome structure and functioning. Nat Rev Microbiol 16:567-576. doi:10.1038/s41579-018-0024-1

5. Bardgett RD, Mawdsley JL, Edwards S, Hobbs PJ, Rodwell JS, Davies WJ (1999) Plant species and nitrogen effects on soil biological properties of temperate upland grasslands: Soil biological properties of upland grasslands. Funct Ecol 13:650-660. doi:10.1046/j.1365-2435.1999.00362.x

6. Benjamini Y, Hochberg Y (1995) Controlling the False Discovery Rate: A Practical and Powerful Approach to Multiple Testing. J Roy Stat Soc: Ser B (Methodol) 57:289-300. doi:10.1111/j.25176161.1995.tb02031.x

7. Berg G, Smalla K (2009) Plant species and soil type cooperatively shape the structure and function of microbial communities in the rhizosphere: Plant species, soil type and rhizosphere communities. FEMS Microbiol Ecol 68:1-13. doi:10.1111/j.1574-6941.2009.00654.x

8. Bever JD (2003) Soil community feedback and the coexistence of competitors: conceptual frameworks and empirical tests. New Phytol 157:465-473. doi:10.1046/j.1469-8137.2003.00714.x

9. Bobbink R, Hicks K, Galloway J, Spranger T, Alkemade R, Ashmore M, Bustamante M, Cinderby S, Davidson E, Dentener F, Emmett B, Erisman J-W, Fenn M, Gilliam F, Nordin A, Pardo L, De Vries W (2010) Global assessment of nitrogen deposition effects on terrestrial plant diversity: a synthesis. Ecol Appl 20:30-59. doi:10.1890/08-1140.1

10. Borer ET, Seabloom EW, Gruner DS, Harpole WS, Hillebrand H, Lind EM, Adler PB, Alberti J, Anderson TM, Bakker JD, Biederman L, Blumenthal D, Brown CS, Brudvig LA, Buckley YM, Cadotte M, Chu C, Cleland EE, Crawley MJ, Daleo P, Damschen El, Davies KF, DeCrappeo NM, Du G, Firn J, Hautier Y, Heckman RW, Hector A, HilleRisLambers J, Iribarne O, Klein JA, Knops JMH, La Pierre KJ, Leakey ADB, Li W, MacDougall AS, McCulley RL, Melbourne BA, Mitchell CE, Moore JL, Mortensen B, O'Halloran LR, Orrock JL, Pascual J, Prober SM, Pyke DA, Risch AC, Schuetz M, Smith MD, Stevens CJ, Sullivan LL, Williams RJ, Wragg PD, Wright JP, Yang LH (2014) Herbivores and nutrients control grassland plant diversity via light limitation. Nature 508, 517-520. doi:10.1038/nature13144

11. Chen Q-L, Ding J, Zhu Y-G, He J-Z, Hu H-W (2020) Soil bacterial taxonomic diversity is critical to maintaining the plant productivity. Environ Int 140:105766. doi:10.1016/j.envint.2020.105766

12. Chen S, Zhou Y, Chen Y, Gu J (2018) fastp: an ultra-fast all-in-one FASTQ preprocessor. Bioinformatics 34:i884-i890. doi:10.1093/bioinformatics/bty560

13. Chen Y, Li J, Ju W, Ruan H, Qin Z, Huang Y, Jeelani N, Padarian J, Propastin P (2017) Quantitative assessments of water-use efficiency in Temperate Eurasian Steppe along an aridity gradient. PLoS ONE 12:e0179875. doi:10.1371/journal.pone. 0179875

14. Chen Y-L, Xu T-L, Veresoglou SD, Hu H-W, Hao Z-P, Hu Y-J, Liu L, Deng Y, Rillig MC, Chen B-D (2017) Plant diversity represents the prevalent determinant of soil fungal community structure across 
temperate grasslands in northern China. Soil Biol Biochem 110:12-21.

doi:10.1016/j.soilbio.2017.02.015

15. Contosta AR, Frey SD, Cooper AB (2015) Soil microbial communities vary as much over time as with chronic warming and nitrogen additions. Soil Biol Biochem 88:19-24.

doi:10.1016/j.soilbio.2015.04.013

16. de Vries FT, Griffiths RI, Bailey M, Craig H, Girlanda M, Gweon HS, Hallin S, Kaisermann A, Keith AM, Kretzschmar M, Lemanceau P, Lumini E, Mason KE, Oliver A, Ostle N, Prosser JI, Thion C, Thomson B, Bardgett RD (2018) Soil bacterial networks are less stable under drought than fungal networks. Nat Commun 9:3033. doi:10.1038/s41467-018-05516-7

17. Delgado-Baquerizo M, Maestre FT, Gallardo A, Bowker MA, Wallenstein MD, Quero JL, Ochoa V, Gozalo B, García-Gómez M, Soliveres S, García-Palacios P, Berdugo M, Valencia E, Escolar C, Arredondo T, Barraza-Zepeda C, Bran D, Carreira JA, Chaieb M, Conceição AA, Derak M, Eldridge DJ, Escudero A, Espinosa Cl, Gaitán J, Gatica MG, Gómez-González S, Guzman E, Gutiérrez JR, Florentino A, Hepper E, Hernández RM, Huber-Sannwald E, Jankju M, Liu J, Mau RL, Miriti M, Monerris J, Naseri K, Noumi Z, Polo V, Prina A, Pucheta E, Ramírez E, Ramírez-Collantes DA, Romão R, Tighe M, Torres D, Torres-Díaz C, Ungar ED, Val J, Wamiti W, Wang D, Zaady E (2013) Decoupling of soil nutrient cycles as a function of aridity in global drylands. Nature 502:672-676. doi:10.1038/nature12670

18. Delgado-Baquerizo M, Reich PB, Trivedi C, Eldridge DJ, Abades S, Alfaro FD, Bastida F, Berhe AA, Cutler NA, Gallardo A, García-Velázquez L, Hart SC, Hayes PE, He J-Z, Hseu Z-Y, Hu H-W, Kirchmair M, Neuhauser S, Pérez CA, Reed SC, Santos F, Sullivan BW, Trivedi P, Wang J-T, Weber-Grullon L, Williams MA, Singh BK (2020) Multiple elements of soil biodiversity drive ecosystem functions across biomes. Nat Ecol Evol 4:210-220. doi:10.1038/s41559-019-1084-y

19. Dunn RM, Mikola J, Bol R, Bardgett RD (2006) Influence of microbial activity on plant-microbial competition for organic and inorganic nitrogen. Plant Soil 289:321-334. doi:10.1007/s11104-0069142-z

20. Edgar RC (2013) UPARSE: highly accurate OTU sequences from microbial amplicon reads. Nat Methods 10:996-998. doi:10.1038/nmeth.2604

21. Erisman JW, Galloway JN, Seitzinger S, Bleeker A, Dise NB, Petrescu AMR, Leach AM, de Vries W (2013) Consequences of human modification of the global nitrogen cycle. Philosophical Trans Royal Soc B: Biol Sci 368:20130116. doi:10.1098/rstb.2013.0116

22. Fan K, Delgado-Baquerizo M, Guo X, Wang D, Zhu Y, Chu H (2021) Biodiversity of key-stone phylotypes determines crop production in a 4-decade fertilization experiment. ISME J 15:550-561. doi:10.1038/s41396-020-00796-8

23. Fan K, Delgado-Baquerizo M, Zhu Y, Chu H (2020) Crop production correlates with soil multitrophic communities at the large spatial scale. Soil Biol Biochem 151:108047. doi:10.1016/j.soilbio.2020.108047

24. Fan M, Li J, Tang Z, Shangguan Z (2020) Soil bacterial community succession during desertification in a desert steppe ecosystem. Land Degrad Dev 31:1662-1674. doi:10.1002/ldr.3545 
25. Gadgil M, Solbrig OT (1972) The Concept of r-and K-Selection: Evidence from Wild Flowers and Some Theoretical Considerations. Am Nat 106:14-31. doi:10.1086/282748

26. Harpole WS, Ngai JT, Cleland EE, Seabloom EW, Borer ET, Bracken MES, Elser JJ, Gruner DS, Hillebrand H, Shurin JB, Smith JE (2011) Nutrient co-limitation of primary producer communities: Community co-limitation. Ecol Lett 14:852-862. doi:10.1111/j.1461-0248.2011.01651.x

27. Hautier Y, Niklaus PA, Hector A (2009) Competition for Light Causes Plant Biodiversity Loss After Eutrophication. Science 324:636-638. doi:10.1126/science.1169640

28. Hautier Y, Seabloom EW, Borer ET, Adler PB, Harpole WS, Hillebrand H, Lind EM, MacDougall AS, Stevens CJ, Bakker JD, Buckley YM, Chu C, Collins SL, Daleo P, Damschen El, Davies KF, Fay PA, Firn J, Gruner DS, Jin VL, Klein JA, Knops JMH, La Pierre KJ, Li W, McCulley RL, Melbourne BA, Moore JL, O'Halloran LR, Prober SM, Risch AC, Sankaran M, Schuetz M, Hector A (2014) Eutrophication weakens stabilizing effects of diversity in natural grasslands. Nature 508:521-525. doi:10.1038/nature13014

29. Hortal S, Lozano YM, Bastida F, Armas C, Moreno JL, Garcia C, Pugnaire FI (2017) Plant-plant competition outcomes are modulated by plant effects on the soil bacterial community. Sci Rep 7:17756. doi:10.1038/s41598-017-18103-5

30. Hu S, Chapin FS, Firestone MK, Field CB, Chiariello NR (2001) Nitrogen limitation of microbial decomposition in a grassland under elevated CO2. Nature 409:188-191. doi:10.1038/35051576

31. Huang J, Xu Y, Yu H, Zhu W, Wang P, Wang B, Na X (2021) Soil prokaryotic community shows no response to 2 years of simulated nitrogen deposition in an arid ecosystem in northwestern China. Environ Microbiol 23:1222-1237. doi:10.1111/1462-2920.15364

32. Kardol P, Cornips NJ, van Kempen MML, Bakx-Schotman JMT, van der Putten WH (2007) MICROBEMEDIATED PLANT-SOIL FEEDBACK CAUSES HISTORICAL CONTINGENCY EFFECTS IN PLANT COMMUNITY ASSEMBLY. Ecol Monogr 77:147-162. doi:10.1890/06-0502

33. Keymer DP, Lankau RA (2017) Disruption of plant-soil-microbial relationships influences plant growth. J Ecol 105:816-827. doi:10.1111/1365-2745.12716

34. Lau JA, Lennon JT (2011) Evolutionary ecology of plant-microbe interactions: soil microbial structure alters selection on plant traits. New Phytol 192:215-224. doi:10.1111/j.14698137.2011.03790.x

35. Lefcheck JS (2016) piecewiseSEM: Piecewise structural equation modelling in $r$ for ecology, evolution, and systematics. Methods Ecol Evol 7:573-579. doi:10.1111/2041-210X.12512

36. Li J, Gao R, Chen Y, Xue D, Han J, Wang J, Dai Q, Lin M, Ke X, Zhang W (2020) Isolation and Identification of Microvirga thermotolerans HR1, a Novel Thermo-Tolerant Bacterium, and Comparative Genomics among Microvirga Species. Microorganisms 8:101. doi:10.3390/microorganisms8010101

37. Liu X, Zhang Y, Han W, Tang A, Shen J, Cui Z, Vitousek P, Erisman JW, Goulding K, Christie P, Fangmeier A, Zhang F (2013) Enhanced nitrogen deposition over China. Nature 494:459-462. doi:10.1038/nature11917 
38. Ma Q, Liu X, Li Y, Li L, Yu H, Qi M, Zhou G, Xu Z (2020) Nitrogen deposition magnifies the sensitivity of desert steppe plant communities to large changes in precipitation. $J$ Ecol 108:598-610. doi:10.1111/1365-2745.13264

39. Magoc T, Salzberg SL (2011) FLASH: fast length adjustment of short reads to improve genome assemblies. Bioinformatics 27:2957-2963. doi:10.1093/bioinformatics/btr507

40. McHugh TA, Morrissey EM, Mueller RC, Gallegos-Graves LV, Kuske CR, Reed SC (2017) Bacterial, fungal, and plant communities exhibit no biomass or compositional response to two years of simulated nitrogen deposition in a semiarid grassland: Bacterial, fungal, and plant communities. Environ Microbiol 19:1600-1611. doi:10.1111/1462-2920.13678

41. Panke-Buisse K, Poole AC, Goodrich JK, Ley RE, Kao-Kniffin J (2015) Selection on soil microbiomes reveals reproducible impacts on plant function. ISME J 9:980-989. doi:10.1038/ismej.2014.196

42. Payne RJ, Dise NB, Field CD, Dore AJ, Caporn SJ, Stevens CJ (2017) Nitrogen deposition and plant biodiversity: past, present, and future. Front Ecol Environ 15:431-436. doi:10.1002/fee.1528

43. Ramirez KS, Craine JM, Fierer N (2012) Consistent effects of nitrogen amendments on soil microbial communities and processes across biomes. Glob Change Biol 18:1918-1927. doi:10.1111/j.13652486.2012.02639.x

44. Reynolds HL, Packer A, Bever JD, Clay K (2003) GRASSROOTS ECOLOGY: PLANT-MICROBE-SOIL INTERACTIONS AS DRIVERS OF PLANT COMMUNITY STRUCTURE AND DYNAMICS. Ecology 84:2281-2291. doi:10.1890/02-0298

45. Schlatter DC, Bakker MG, Bradeen JM, Kinkel LL (2015) Plant community richness and microbial interactions structure bacterial communities in soil. Ecology 96:134-142. doi:10.1890/13-1648.1

46. Shannon CE, Weaver W, Wiener N (1950) The Mathematical Theory of Communication. Phys Today 3:31-32. doi:10.1063/1.3067010

47. Shao Y, Liu T, Eisenhauer N, Zhang W, Wang X, Xiong Y, Liang C, Fu S (2018) Plants mitigate detrimental nitrogen deposition effects on soil biodiversity. Soil Biol Biochem 127:178-186. doi:10.1016/j.soilbio.2018.09.022

48. Stackebrandt E, Goebel BM (1994) Taxonomic Note: A Place for DNA-DNA Reassociation and $16 S$ rRNA Sequence Analysis in the Present Species Definition in Bacteriology. Int J Syst Evol MicroBiol 44:846-849. doi:10.1099/00207713-44-4-846

49. Stevens CJ, Dise NB, Mountford JO, Gowing DJ (2004) Impact of Nitrogen Deposition on the Species Richness of Grasslands. Science 303:1876-1879. doi:10.1126/science.1094678

50. Su J, Li X, Li, Xiaojun, Feng L (2013) Effects of additional N on herbaceous species of desertified steppe in arid regions of China: a four-year field study. Ecol Res 28:21-28. doi:10.1007/s11284-0120994-9

51. Tang Z, Deng L, An H, Yan W, Shangguan Z (2017) The effect of nitrogen addition on community structure and productivity in grasslands: A meta-analysis. Ecol Eng 99:31-38.

doi:10.1016/j.ecoleng.2016.11.039 
52. Treseder KK (2008) Nitrogen additions and microbial biomass: a meta-analysis of ecosystem studies. Ecol Lett 11:1111-1120. doi:10.1111/j.1461-0248.2008.01230.x

53. van der Putten WH (2017) Belowground drivers of plant diversity. Science 355:134-135. doi:10.1126/science.aal4549

54. Wang H, Ta N, Jin K, Ji B, Schellenberg MP, Wei Z, Wang Z (2020) Interactive effects of nitrogen fertilizer and altered precipitation on fungal communities in arid grasslands of northern China. $J$ Soils Sediments 20:1344-1356. doi:10.1007/s11368-019-02512-2

55. Wang Q, Garrity GM, Tiedje JM, Cole JR (2007) Naïve Bayesian Classifier for Rapid Assignment of rRNA Sequences into the New Bacterial Taxonomy. Appl Environ Microbiol 73:5261-5267. doi:10.1128/AEM.00062-07

56. Wang Z, Na R, Koziol L, Schellenberg MP, Li X, Ta N, Jin K, Wang H (2020) Response of bacterial communities and plant-mediated soil processes to nitrogen deposition and precipitation in a desert steppe. Plant Soil 448:277-297. doi:10.1007/s11104-020-04424-4

57. Wu Q, Ren H, Bisseling T, Chang SX, Wang, Zhen, Li Y, Pan Z, Liu Y, Cahill JF, Cheng X, Zhao M, Wang Z, Li Z, Han G (2021) Long-Term Warming and Nitrogen Addition Have Contrasting Effects on Ecosystem Carbon Exchange in a Desert Steppe. Environ Sci Technol 55:7256-7265. doi:10.1021/acs.est.0c06526

58. Yang X, Huang Z, Dong M, Ye X, Liu G, Hu D, Tuvshintogtokh I, Tumenjargal T, Cornelissen JHC (2019) Responses of community structure and diversity to nitrogen deposition and rainfall addition in contrasting steppes are ecosystem-dependent and dwarfed by year-to-year community dynamics. Ann Botany 124:461-469. doi:10.1093/aob/mcz098

59. Yu G, Jia Y, He N, Zhu J, Chen Z, Wang Q, Piao S, Liu X, He H, Guo X, Wen Z, Li P, Ding G, Goulding K (2019) Stabilization of atmospheric nitrogen deposition in China over the past decade. Nat Geosci 12:424-429. doi:10.1038/s41561-019-0352-4

60. Zhang H, Shi Y, Dong Y, Lapen DR, Liu J, Chen W (2022) Subsoiling and conversion to conservation tillage enriched nitrogen cycling bacterial communities in sandy soils under long-term maize monoculture. Soil Tillage Res 215:105197. doi:10.1016/j.still.2021.105197

61. Zhang T, Chen HYH, Ruan H (2018) Global negative effects of nitrogen deposition on soil microbes. ISME J 12:1817-1825. doi:10.1038/s41396-018-0096-y

62. Zilber-Rosenberg I, Rosenberg E (2008) Role of microorganisms in the evolution of animals and plants: the hologenome theory of evolution. FEMS Microbiol Rev 32:723-735. doi:10.1111/j.15746976.2008.00123.x

\section{Figures}



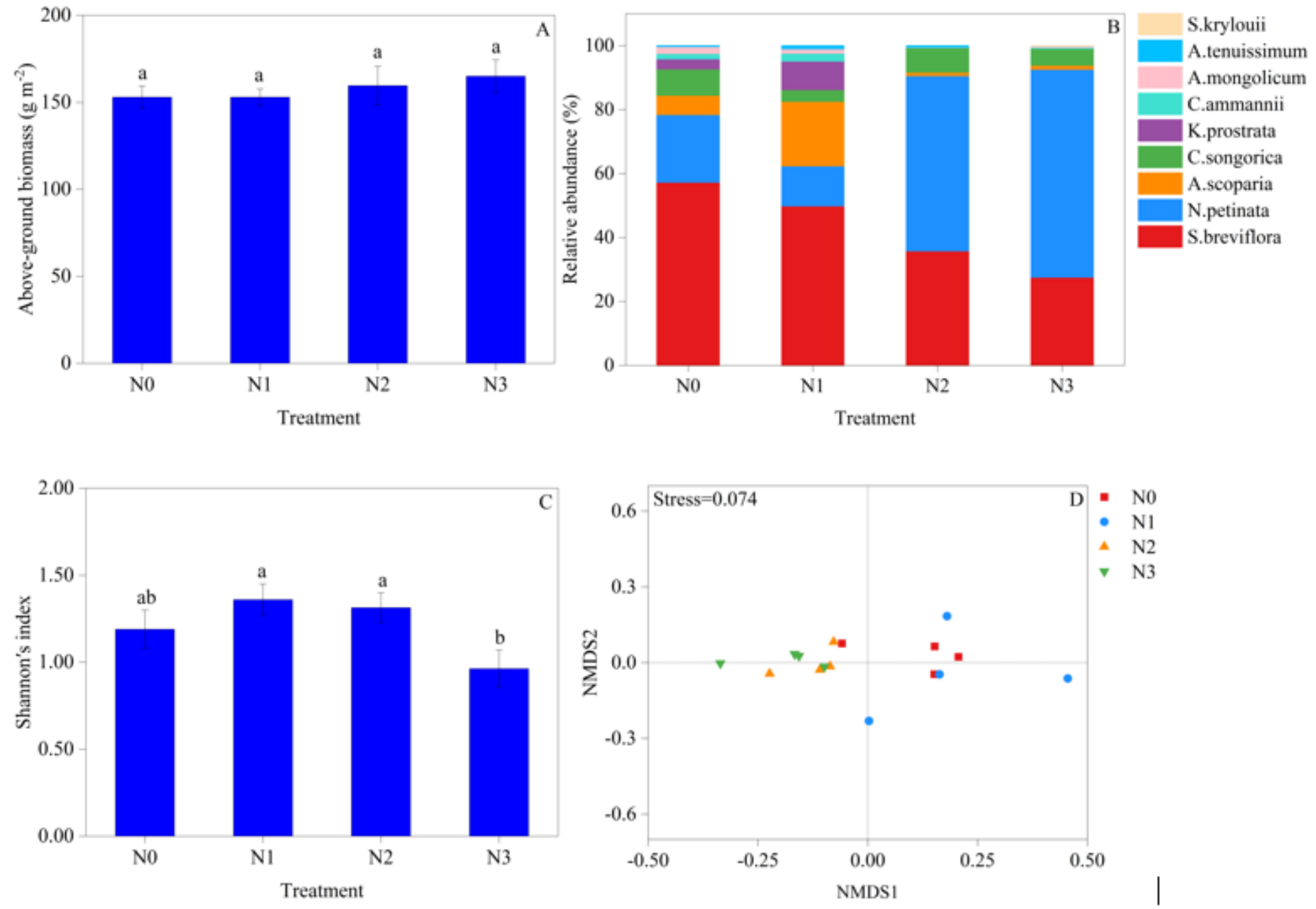

\section{Figure 1}

Changes of above-ground biomass(A), community composition(B), alpha (Shannon's index(C)) and beta diversity (NMDS(D)) of plants. Lowercase letters indicate that there are significant differences among the treatments $(P<0.05)$. Data are shown as mean $\pm \mathrm{SE}$. The following is the same. 

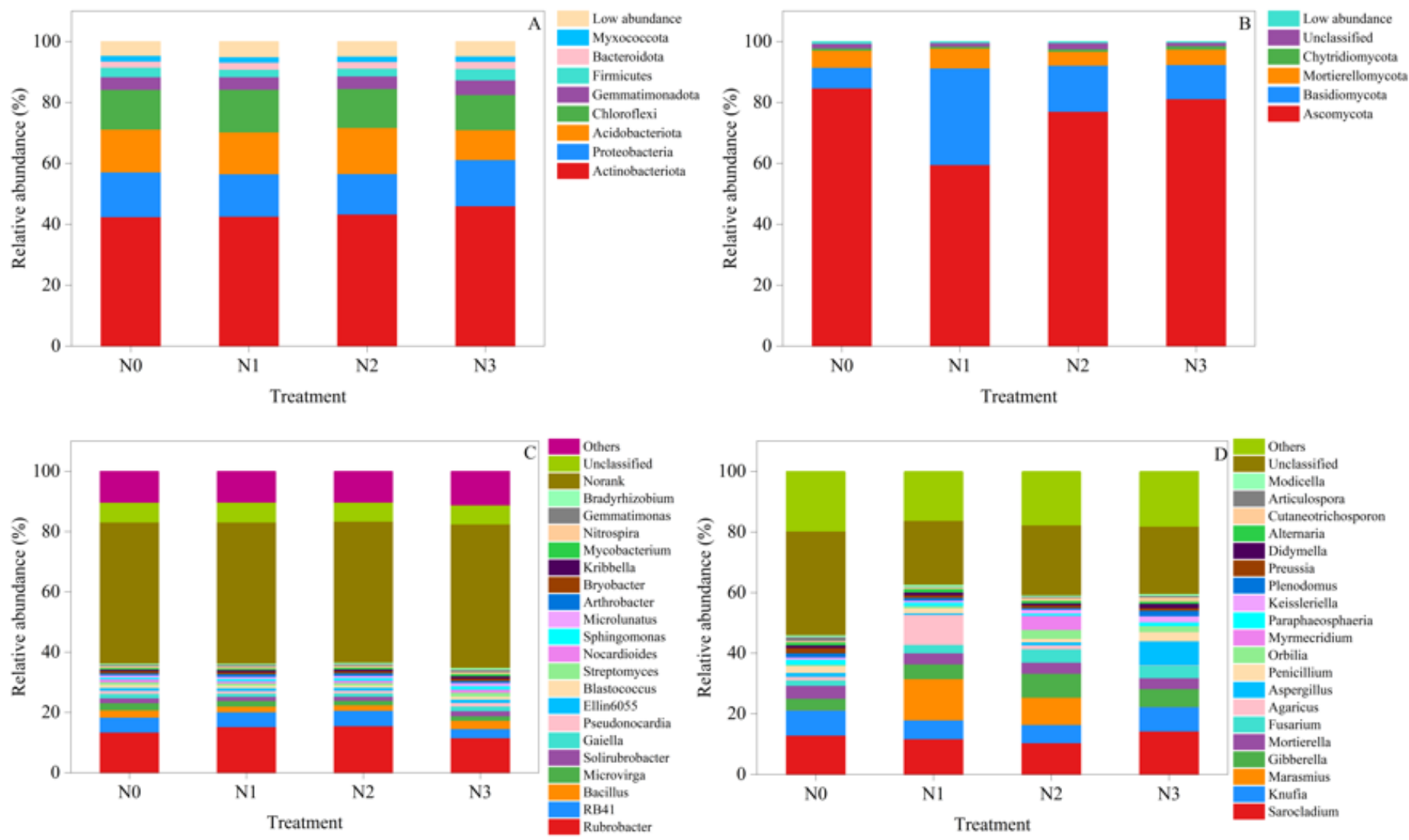

Figure 2

Relative abundance of soil bacterial (A) and fungal (B) communities at the phylum level, and soil bacterial (C) and fungal (D) communities at the genus level 

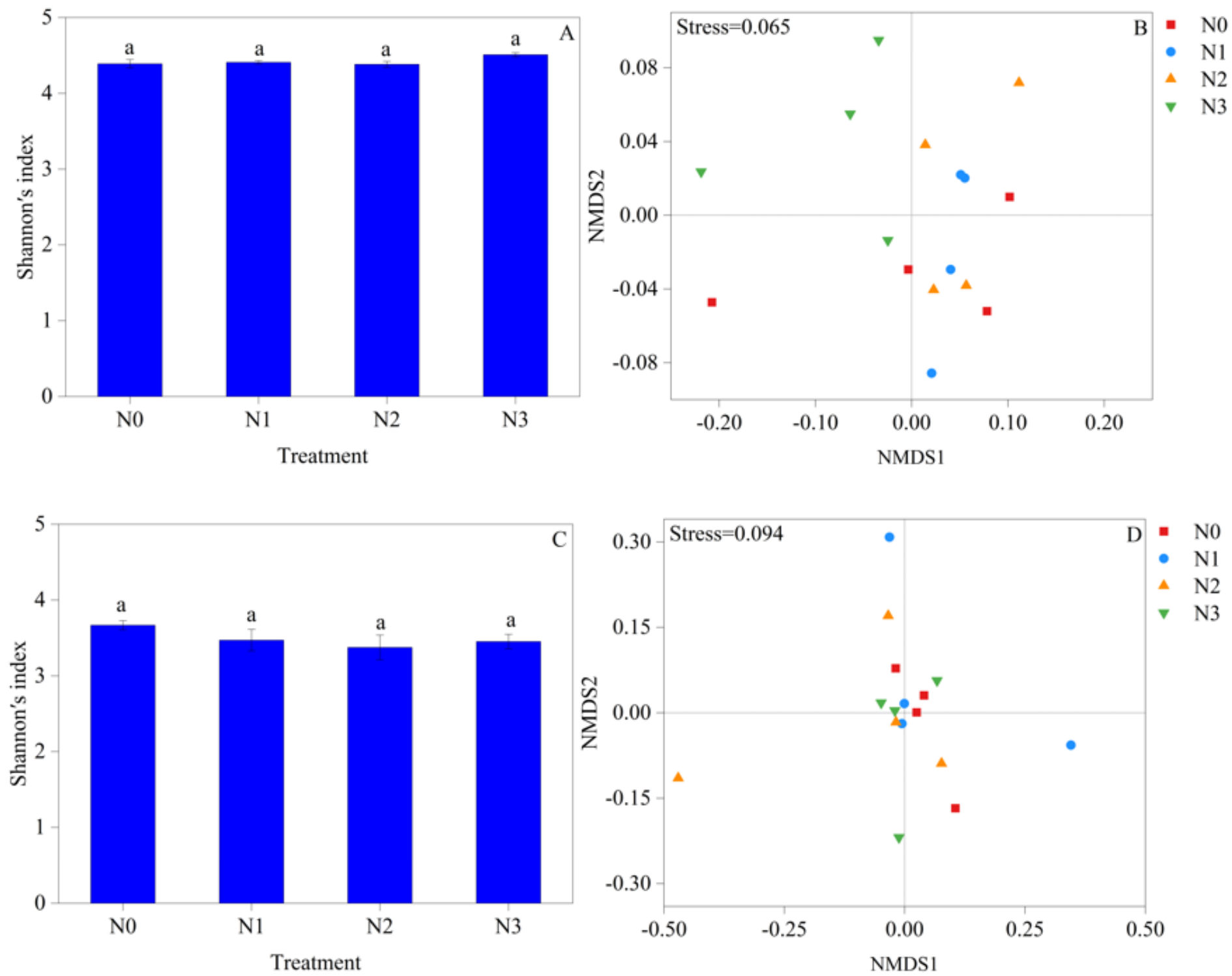

Figure 3

Alpha (Shannon's index(A)) and beta diversity (NMDS(B)) of the bacterial communities. Alpha (Shannon's index(C)) and beta diversity (NMDS(D)) of the fungal communities. Dissimilarities between communities were calculated by Bray-Curtis distance based on the relative abundance of the genus. 


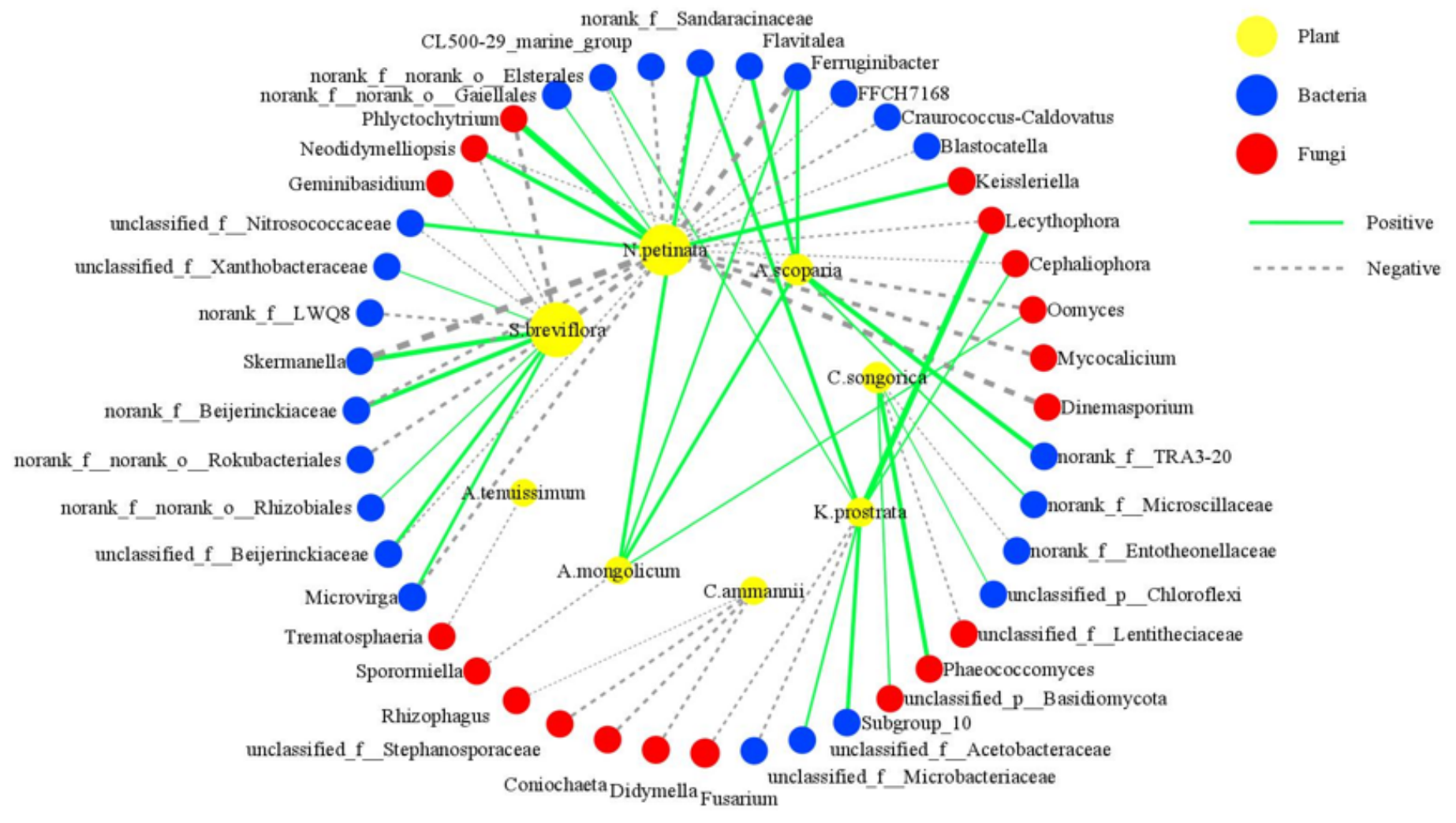

\section{Figure 4}

Correlation network visualization of the interaction strengths. Spearman's rank correlations of the relative abundances of all species between two groups were calculated. Line colour and width are proportional to the interaction strength, as indicated in the legend in the figure. The size of the circles is proportional to the number of species/taxa in that group. The following is the same.

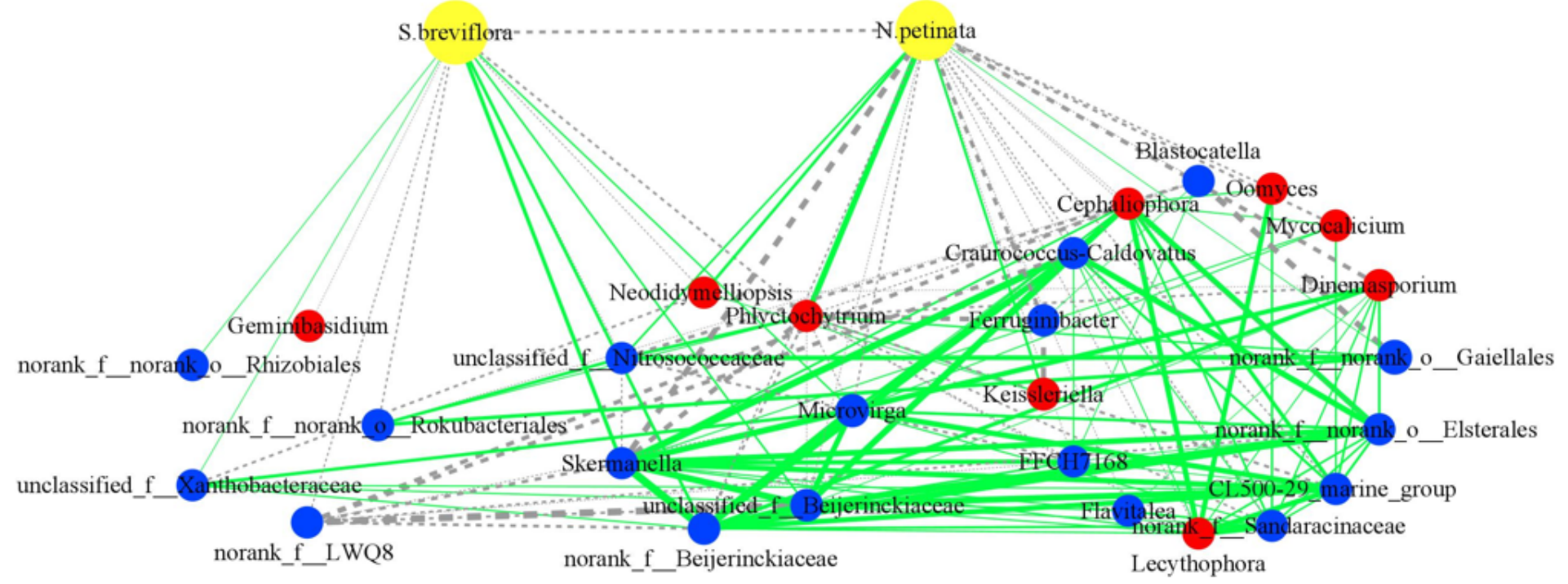

Figure 5 
Effects of N-addition on S.breviflora, N.petinata and soil microbial networks. The proportion of correlations $>0.6$ was divided by the total number of possible interactions to obtain the interaction strength between two groups of species.

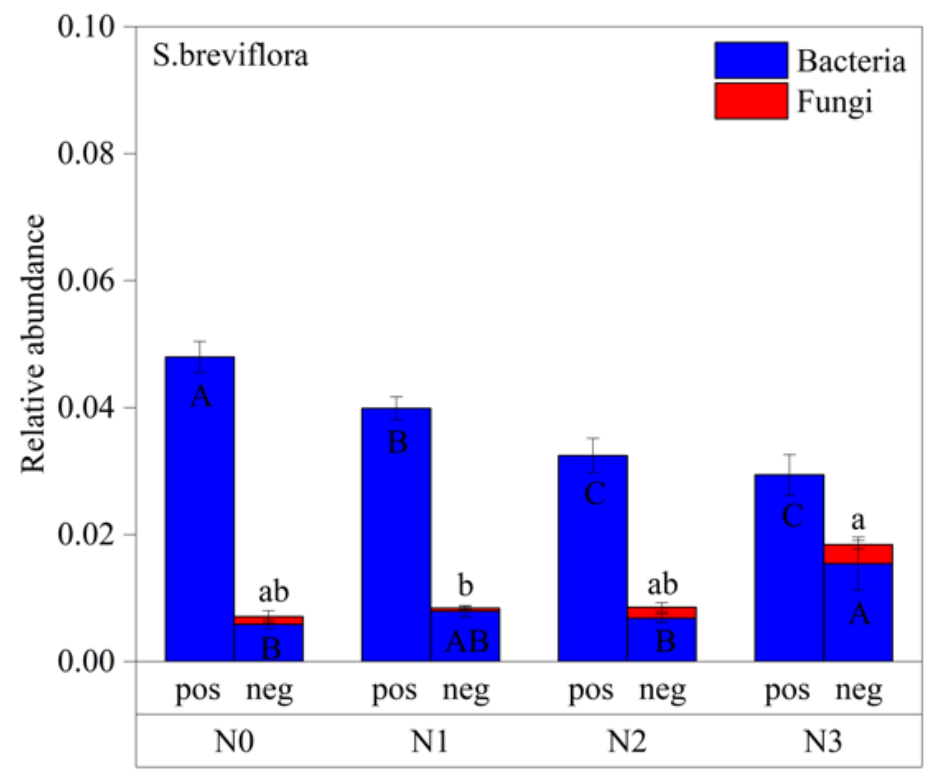

Treatment

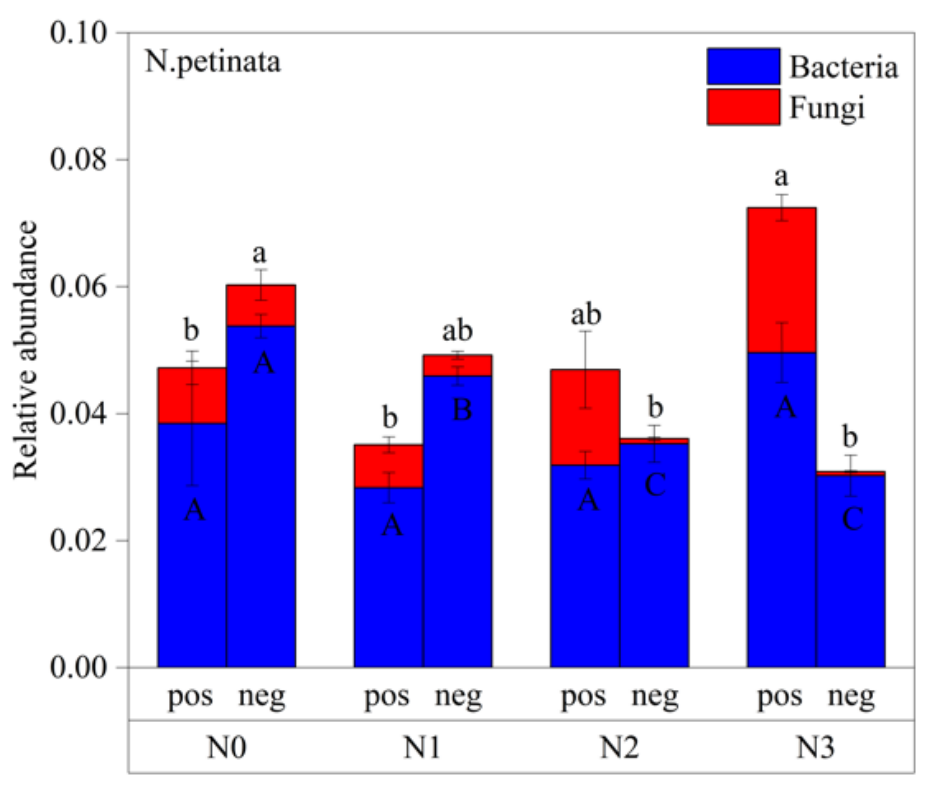

Treatment

Figure 6

Relative abundance of correlated microbes at the genus level. Within each graph, different capital-case and lower-case letters indicate a significant $(P<0.05)$ difference under different treatments according to Duncan test. Vertical bars represent standard errors. pos: positive correlation; neg: negative correlation. 


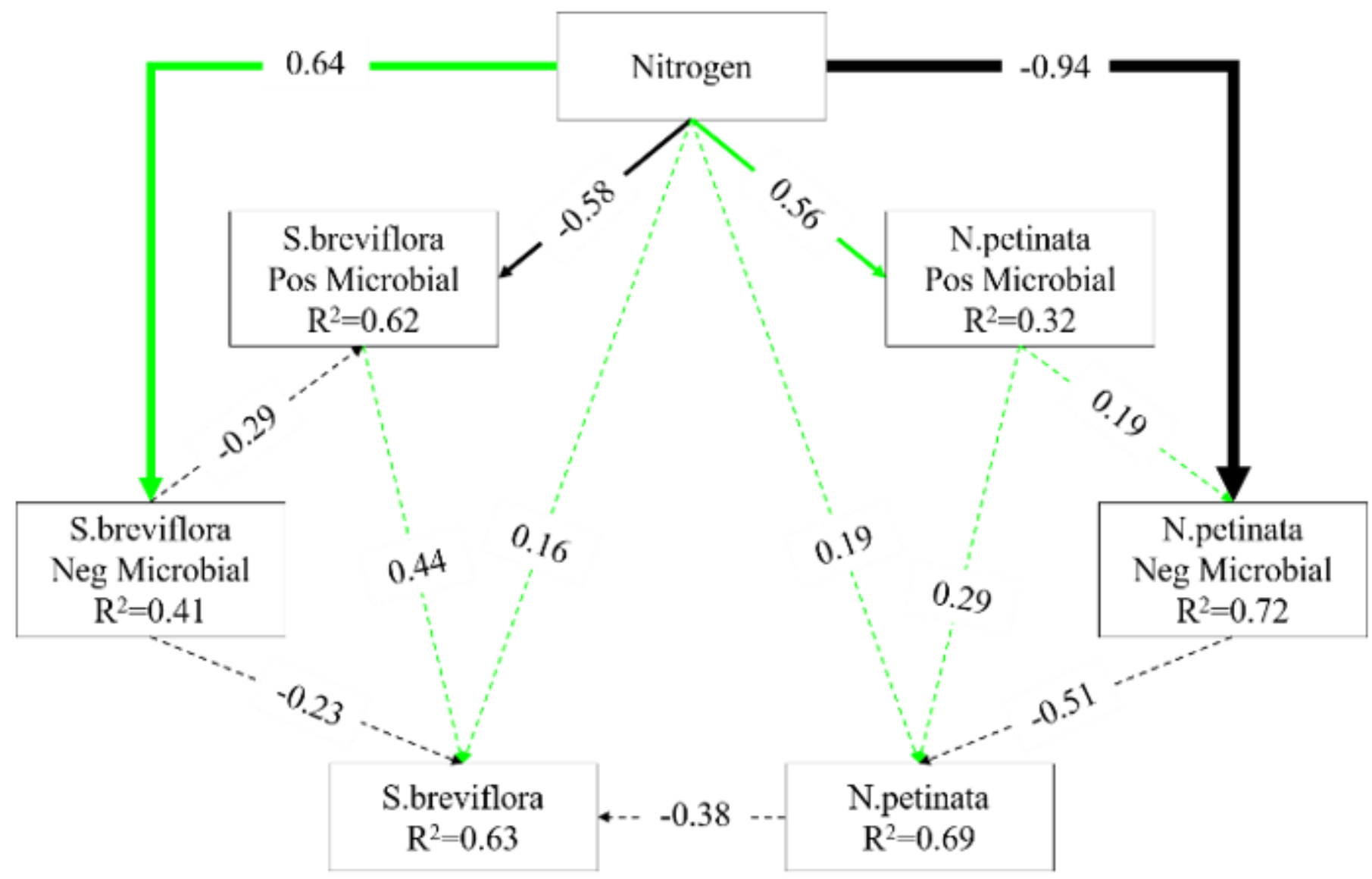

Figure 7

Structural equation modeling analysis of the N-addition effects (via direct and indirect effects of plants and microbes) on positive correlation microbial, negative correlation microbial, and plant. The results of model fitting: Fisher's $C=15.848, P=0.198,12$ degrees of freedom. The green and black arrows indicate significant positive and negative effects $(P<0.05)$. The dotted line is not significant $(P>0.05)$. Values associated with arrows represent standardized path coefficients. Arrow width is proportional to the strength of path coefficients. $\mathrm{R}^{2}$ values associated with response variables indicate the proportion of variation explained by relationships with other variables. 